How to cite this article:

Adams, D., Mabel, H. J. T., Sumintono, B., \& Oh, S. P. (2020). Blended learning engagement in higher education institutions: A differential item functioning analysis of students' backgrounds. Malaysian Journal of Learning \& Instruction, 17(1), 133-158. https://doi.org/10.32890/mjli2020.17.1.6

\title{
BLENDED LEARNING ENGAGEMENT IN HIGHER EDUCATION INSTITUTIONS: A DIFFERENTIAL ITEM FUNCTIONING ANALYSIS OF STUDENTS' BACKGROUNDS
}

\author{
${ }^{1}$ Donnie Adams, ${ }^{2}$ Mabel Tan Hwee Joo, ${ }^{3}$ Bambang Sumintono \\ $\&{ }^{4} \mathrm{Oh}$ Siew Pei \\ ${ }^{1,3}$ Faculty of Education, University of Malaya, Malaysia \\ ${ }^{2,4}$ UCSI University, Kuala Lumpur, Malaysia \\ ICorresponding author:donnieadams@um.edu.my
}

Received: 14/10/2019 Revised: 29/12/2019 Accepted: 10/1/2020 Published: 31/1/2020

\section{ABSTRACT}

Purpose - Digital technology has transformed teaching and learning in such a way that it seems imperative lecturers and institutions need to adapt and adopt a blended learning model of instruction across disciplines. However, there is a scarcity of studies to determine the degree of students' engagement on blended or online university courses. The purpose of the study is to investigate students' cognitive engagement, emotional engagement, and behavioural engagement in a blended learning model of instruction as well as specifically assess their engagement based on demographic factors such as age, gender, field of study, ethnicity, and type of institution in leading Malaysian public and private higher education institutions.

Methodology - A non-experimental quantitative research design was employed in this study. 462 undergraduate and postgraduate students were sampled using the Blended Learning Readiness Engagement Questionnaire ${ }^{\odot}$. Subsequently, WINSTEPS Rasch model measurement software was used to determine the reliability and validity of the research instrument. Descriptive statistics and 
differential item functioning (DIF) were conducted to assess students' engagement in a blended learning model of instruction with the latter analysing specifically on student's demographic factors such as age, gender, field of study, ethnicity, and type of institution.

Findings - Findings show high levels of engagement in blended learning activities among students in both public and private higher education institutions based on their cognitive, emotional, and behavioural engagement processes. Findings also indicates differences in students' engagement based on demographic factors such as age, gender, field of study, ethnicity, and type of institution.

Significance - The findings of this study will help lecturers reflect on their own teaching practices in this era of technology advancement where a blended learning model of instruction are given increased prioritisation and proliferation. Implications and recommendations for future research in blended learning practices are presented.

Keywords: Student engagement, Blended learning, higher education institution, Rasch model.

\section{INTRODUCTION}

The revolution and rapid development in computer software and Internet technologies in the last decade has seen the evolvement of tertiary education (Tayebinik \& Puteh, 2012). Particularly, distance education was introduced to revolutionised teaching and learning. Emerging concepts then begun to emerge such as online learning or e-learning, largely in higher education, leading to a flurry of studies comparing the effectiveness of face-to-face and e-learning environments (Northey, Bucic, Chylinski, \& Govind, 2015; Southard, Meddaug, \& Harris, 2015), the advantages and disadvantages of e-learning (Wang, 2010), and students' learning outcomes (Bernard, Borokhovski, Schmid, Tamim, \& Abrami, 2014; Ryan, Kaufman, Greenhouse, She, \& Shi, 2016).

However, the inhabitation of socialisation and face-to-face communication among students are among the few disadvantages of e-learning environments resulting in the emergence of a new concept termed blended learning (Tayebinik \& Puteh, 2012), a combination of both face-to-face and e-learning environments (Azizan, 2010). As 
a result, many lecturers in higher education institutions adopted a blended instruction as they believed the new concept would enhance students' outcome and enrich their learning experiences (Lim \& Morris, 2009). Blended learning is now widely adopted across higher education institutions with some scholars referring to it as the 'new norm' in course delivery (Dziuban, Graham, Moskal, Norberg, \& Sicilia, 2018).

Students' engagement includes what individuals feel (emotional), think (cognitive), and plan to do (behavioural). There is little empirical research focusing exclusively on students' engagement in blended learning experiences in Malaysia. Hence the purpose of this study is to investigate students' engagement in blended learning based on cognitive engagement, emotional engagement, and behavioural engagement as well as specifically assess their engagement based on age, gender, field of study, ethnicity, and type of institution in leading Malaysian public and private higher education institutions. The following section provides a review of blended learning and students' engagement in blended learning in higher education institutions. Subsequently, the methodology are discussed. This is followed by the results, discussion, and finally, the conclusion.

\section{LITERATURE REVIEW}

\section{Blended Learning}

In 2012, the Malaysia Education Blueprint 2013-2025 was introduced to transform the Malaysian education system (A. Ghani, 2013). The Blueprint offers an education vision in 11 operational shifts with a particular attention in shift seven to leverage on information and communications technology (ICT) to upgrade the quality of student learning. In accordance with the government's vision of giving quality Internet-enabled education for all, along with the technological advancement of the 21st century, the Malaysian Ministry of Education made online learning a key initiative and integral component of lifelong learning in higher education. "Blended learning models will become a staple pedagogical approach in all higher learning institutions, requiring up to $70 \%$ of programmes to use blended learning models" (Ministry of Education, 2012, p. E-16). 
Graham, Woodfield, and Harrison (2013) defined blended learning as a thoughtful integration of traditional face-to-face instruction with technology-mediated instruction. The practice of blended learning in higher education and its accompanying research are increasing across the years (Drysdale, Graham, Spring, \& Halverson, 2013; Fisher, Perényi, \& Birdthistle, 2018; Maroco, Maroco, Campos, \& Fredricks, 2016). Many studies focus on students' learning outcomes, perceptions, experiences, and their interaction in blended learning model of instruction. Maarop and Embi (2016) highlighted that technology, instructor, technical support, and students' engagement are challenges faced while conducting blended learning.

On the one hand, improving students' engagement has been an important goal in blended learning course design (Manwaring, Larsen, Graham, Henrie, \& Halverson, 2017) to gauge the quality of learning and teaching (Sarıtepeci \& Çakır, 2015). It is important to look into students' engagement to ensure successful implementation of blended learning model of instruction in this era of technology advancement where education emphasised more on blended learning with the increasing proliferation and prioritisation of virtual learning environment.

\section{Students' Engagement in Blended Learning}

Fredricks, Blumenfeld, and Paris (2004) described students' engagement as a complex, multifaceted process presumed to be affected by contextual features. It consists of three components, namely cognitive engagement, behavioural engagement and emotional engagement. Cognitive engagement is the mental process that involves students' knowledge and skills in learning; behavioural engagement is the extent to which student demonstrate positive actions towards the institution, their social circle, the academic subject matter, and extra-curricular activities; and lastly emotional engagement is the student's feelings towards their teachers, institutions and fellow peers (Northey et al., 2015). Therefore, engagement includes what individuals feel (emotional), think (cognitive), and plan to do (behavioural). This is consistent with the concept of students' engagement by Vibert and Shields (2003) that it could be learnt from different aspects, for example emotional, cognitive, and behavioural components. 
Similarly, according to Fisher et al. (2018), students' engagement is a multidimensional construct influenced by many factors and are linked to students' motivation, satisfaction as well as academic performance. Students' engagement has always been linked to students' academic performance (Fisher et al., 2018; Northey et al., 2015; Pellas \& Kazanidis, 2015). Positive engagement of students has been suggested as part of prominent components to the successful integration of blended learning model of instruction in schools (Pellas \& Kazanidis, 2015).

A quasi-experimental study was conducted by Sarıtepeci and Çakır (2015) consisting of 115 Grade Seven students (60 and 55 in the control and experimental group) from four middle schools located in Ayaş, Ankara to analyse the effects of blended learning environment on students' engagement. Results indicate that blended learning had moderate level effects on students' engagement. The authors concluded that blended learning is more effective as compared to face-to-face learning in the development of students' engagement.

This finding is supported by Acelajado's (2011) study, in which there was significant difference in the achievements of 20 students in blended learning strategy and 20 students in traditional faceto-face classroom instruction strategy resulting in the favour of a blended learning strategy. Furthermore, students' had improvements in attitude, as well as increased motivation and enjoyment in lessons (Acelajado, 2011). To this notion, students' engagement in blended learning model of instruction can lead to better students' outcomes including improved cognitive engagement (knowledge and skills), emotional engagement (motivation and enjoyment), and behavioural engagement (attitude).

Helme and Clarke (2001) found that cognitive and emotional components of students' engagement are not two separate entities, but rather complements one another. Studies have shown improved cognitive engagement and emotional engagement through blended learning (Halverson \& Graham, 2019). However, the authors highlighted the importance of further research to clarify such relationships. This is supported by Fredricks et al. (2004), who noted that it is important to find out how students behave, feel, and think to aid in the research development and interventions of students' engagement. 
The outcomes in literature review suggest that while there are studies focusing on measuring students' engagement in blended learning environments (Fisher et al., 2018; Henrie, Bodily, Manwaring, \& Graham, 2015; Manwaring et al., 2017; Sarıtepeci \& Çakır, 2015). There is little empirical research focusing on student engagement in blended learning experiences in Malaysia. Hence, this study aims to investigate students' engagement in a blended learning model of instruction based on cognitive engagement, emotional engagement, and behavioural engagement as well as specifically assess their engagement based on demographic factors such as age, gender, field of study, ethnicity, and type of institution in leading Malaysian public and private higher education institutions.

\section{METHODOLOGY}

\section{Instrumentation}

A cross-sectional quantitative survey method was employed in this study. The Blended Learning Engagement Questionnaire $(B L E Q)^{\odot}$ was developed comprising of five basic demographic questions (i.e., age, gender, field of study, ethnicity, and type of institution), and 16 close-ended items in three dimensions to measure students' engagement for blended learning in two higher education institutions in Kuala Lumpur, Malaysia. The three dimensions along with of its number of items are as follows: emotional engagement (five items), cognitive engagement (four items), and behavioural engagement (seven items). According to Curley, McClure, Spence, and Craig (2002), the close-ended questions will force participants to a quick response, produce the score quickly, and expedite the evaluation. The BLEQ consist of a four-point Likert-type scale for all items ranging from strongly disagree (1) to strongly agree (4).

\section{Participants}

Convenience sampling technique was used with 500 students from various fields of study in one public and one private higher education institution in Kuala Lumpur, Malaysia selected to respond to the online survey. All students consented to take part in this study. It was stated on the front cover of the questionnaire that the students are given the choice either to take part in the survey or otherwise. Participation was strictly anonymous and voluntary to address ethical concerns. Thus, by completing the questionnaire, the students are deemed to have given their consent. 
All collected data were inputted into a Microsoft Excel file, next data was imported into WINSTEPS version 3.73, a Rasch measurement model software for data validation and cleaning. There were 20 respondents who provided outlier responses (18 all maximum ratings and 2 all minimum ratings). There were also misfit responses, where 18 respondents were omitted because their responses differed greatly from the rest (misfit persons). Finally, 462 students' responses were analysed. There were no missing data. The demographic profile of the students is indicated in Table 1.

Table 1

Demographic Data of Students $(N=462)$

\begin{tabular}{lcc}
\hline Demographics & Frequency & Percentage $(\%)$ \\
\hline Gender & 158 & \\
$\quad$ Male & 304 & 34.20 \\
Female & & \\
Age & 187 & 40.48 \\
$\quad$ Below 20 years old & 195 & 42.21 \\
20-29 years old & 79 & \\
Over 29 years old & & \\
Ethnicity & 128 & 27.71 \\
$\quad$ Malay & 230 & 49.79 \\
Chinese & 41 & 8.87 \\
Indian & 15 & 3.25 \\
Sabah-Sarawak & 48 & 10.39 \\
International students & & \\
Field of Study & 287 & 62.12 \\
Social Sciences & 83 & 17.97 \\
Natural Sciences & 35 & 7.58 \\
Engineering & 51 & 11.04 \\
Medicine & & \\
Type of Institution & 250 & 54.11 \\
Public & 212 & 45.89 \\
Private & & \\
\hline
\end{tabular}

\section{Rasch Measurement Model}

Students' engagement in blended learning refers to the students' opinion, perception, or attitude in the activity. This is known as 
latent trait, something hidden, which cannot be observed directly. In order to measure this latent trait, BLEQ instrument was used to gather data, then the Rasch measurement model (Bond \& Fox, 2015) was used to analyse the data for both the instrument quality and person response. Using WINSTEPS version 3.73, the data were mathematically transformed into logit (logarithm odd unit) via the logarithm function (Boone, Townsend, \& Staver, 2016; Sumintono $\&$ Widhiarso, 2014). The logarithm function was used to transform raw ordinal data (Likert-type data) into equal-interval scale. Next, in order to determine the relationship between person ability and item difficulty level, the measurement model was calibrated by the process of conjoint measurement (Engelhard, 2013).

The result from WINSTEPS software was utilised to examine students' engagement in a blended learning environment based on age, gender, field of study, ethnicity, and type of institution using descriptive statistics (mean and standard deviation) scores, (logit) value of item, and (logit) value of person. The mean score is in the form of logit scale. Therefore, if the person logit is positive, the person's perceived engagement for blended learning is higher than the average. If the person logit is negative, the person's perceived engagement for blended learning is lesser than the required average. Higher logit scores indicates higher levels of students' engagement in blended learning.

\section{Validity and Reliability of the Instrument}

Prior to further analysis, the software WINSTEPS version 3.73 was utilized to check the validity and reliability of the instrument. A two-facet (person and item) rating scale model was constructed for 16 blended learning engagement items and 462 respondents using the Rasch model approach to identify responses based on students' demographic profile. The items were centred at zero, which allowed the person to 'float' and calibrate their students' engagement level.

Table 2 reports the reliability indices in logit measures that determine the overall quality and the psychometric properties of the BLEQ. The Person Reliability index (0.92) and Item Reliability index (0.98) indicates that the consistency of person and item responses was 'very good' (Sumintono \& Widhiarso, 2014) and that the reliability of both item and person is very high. The Cronbach's alpha coefficient value (0.93) suggests the BLEQ has 'very good' internal consistency and is considered a highly reliable instrument (Bond \& Fox, 2015). 
In addition, Table 2 shows the BLEQ's Person Separation index (3.37) and the Item Separation index (7.71). Person Separation index and Item Separation index estimate of how well the BLEQ can distinguish between 'Person abilities' in terms of the latent trait and how widespread the items are in defining both the easy and difficult items (Boone, Staver, \& Yale, 2014). The bigger the separation index, the more likely respondents will respond correctly to the items. However, the spread has to be equal or more than three (Fisher, 2007). In this study, the BLEQ's shows a good spread across the range of respondents and items endorsing it as a fit and reliable instrument for identifying students' engagement in blended learning. The BLEQ instrument had a good unidimensionality measure $(53.5 \%)$, with its raw variance above the standard of $40 \%$ (Fisher, 2007), indicating it can effectively measure students' blended learning engagement.

Table 2

Summary of Person and Item Separation Index

\begin{tabular}{lccc}
\hline & Person & Item \\
\hline Separation & 3.37 & & 7.71 \\
Reliability & 0.92 & 0.98 \\
Cronbach's alpha & & 0.93 & \\
Chi-square $\left(\chi^{2}\right)$ & $9267 * *$ & \\
Raw variance explained & & $53.5 \%$ & \\
by measures & & \\
\hline
\end{tabular}

$* * p<0.01$

Furthermore, the outfit mean-square statistics for both person and item is close to 1.0, supported with a significant level of chi-square score, which shows that the data fit the model (Boone et al., 2014; Engelhard, 2013). Additionally, the rating scale analysis in Table 3 indicates the four-rating scale (strongly agree to strongly disagree) was easily understood by the students with a threshold (step) rating scale of 1.4 to 5.0 (Fisher, 2007). Results illustrate that there were no disordered thresholds, the average person measured by category moved up monotonically with the rating scale, meaning that all of the Likert scale categories were well functioning. 
Table 3

Rating Scale Model Category Statistics for the Total Sample $(N=462)$

\begin{tabular}{lccccc}
\hline Category & Frequency & Percentage & $\begin{array}{c}\text { Average } \\
\text { measure }\end{array}$ & $\begin{array}{c}\text { Outfit } \\
\text { MNSQ }\end{array}$ & Step \\
\hline 1 (SD) & 85 & $1 \%$ & -2.73 & 1.19 & NONE \\
$2(\mathrm{D})$ & 1428 & $19 \%$ & -0.17 & 1.01 & -4.24 \\
$3(\mathrm{~A})$ & 4366 & $59 \%$ & +2.01 & 0.97 & -0.21 \\
$4(\mathrm{SA})$ & 1513 & $20 \%$ & +4.89 & 0.98 & +4.47 \\
\hline
\end{tabular}

\section{RESULTS}

Level of students' engagement in blended learning in the Malaysian public and private higher education institutions

Table 4

Summary (Logit) Value of Person and Item

\begin{tabular}{lcc}
\hline & Person & Item \\
\hline $\mathrm{N}$ & 462 & 16 \\
Measures (logit) & & \\
$\quad$ Mean & 2.12 & 0.00 \\
SD, standard deviation & 2.16 & 0.82 \\
SE, standard error & 0.07 & 0.00 \\
Outfit Mean Square & & \\
$\quad$ Mean & 0.97 & 0.97 \\
SD & 0.52 & 0.23 \\
\hline
\end{tabular}

First, students' engagement in blended learning was analysed. Findings in Table 4 shows the mean measure (logit) value of person was +2.12 logit. This indicates that all students were highly engaged in the blended learning activities. A standard deviation of 2.16 indicates a very wide dispersion level. As for the mean measure 
(logit) value of item, the mean is 0.00 logit and the standard deviation is 0.82 . This suggests a wide dispersion of measures across the logit scale in item difficulty level.

\section{Item Difficulty Level}

Table 5 classifies the items according to their item difficulty level or logit value of item (LVI). The classification of the items into four difficulty levels was done by dividing the distribution of the item logit score based on mean and standard deviation (as shown in Table 4). There were three items (19\%) in the category of very difficult to agree by respondents (LVI $>0.82$ logit); in the second category, which is difficult to agree $(+0.82 \geq \mathrm{LVI} \geq 0.00)$, there were five items (31\%); the next category which is easy to agree by respondents $(0.00$ $\geq$ LVI $\geq-0.82$ ), there were four items ( $25 \%$ ); and lastly, four items (25\%) fall into the category of very easy to agree by the respondents (LVI $<-0.82$ logit).

Table 5

Blended Learning Engagement Item Calibration

\begin{tabular}{lcccc}
\hline & \multicolumn{4}{c}{ Difficulty level } \\
\cline { 2 - 5 } $\begin{array}{l}\text { Construct of } \\
\text { Engagement }\end{array}$ & Very Difficult & Difficult & Easy & Very easy \\
\hline Cognitive & C2, C3 & C4 & - & C1 \\
Emotional & E2 & E4, E5, E3 & E1 & - \\
Behaviour & - & B1 & B5, B2, B7 & B3, B4, B6 \\
\hline
\end{tabular}

As shown in Table 5, behaviour engagement in blended leaning tends to be easy for the students, where six out of seven items fall into the categories of easy and very easy to agree, whereas cognitive and emotional dimensions are more difficult to engage by the students (seven out of nine items). This indicate that students do not have much difficulty to engage in behavioural engagement compared to cognitive and emotional engagement process which involves thinking and psychological attachment. 


\section{Person Level of Engagement in Blended Learning}

Table 6 categorises students into four levels of blended learning engagement (very high level to low level of engagement). Using the demographic profile of students and its logit value of person (LVP), the table below provides details of each group's level of participation.

Analysis of students' gender observed 75 out of 158 male students $(47 \%)$ and 138 out of 304 female students $(45 \%)$ were in very highand high-level engagement of blended learning. In the moderate level engagement, there were 65 male students (41\%) and 122 female students (40\%); students who were low-level blended learning engagement is the least (11\% and $14 \%$ respectively for male and female students).

In terms of age, $50 \%$ (40 students) aged over 29 consider themselves in very high- and high-level engagement, which were similar to those aged below 20 ( 88 students or 47\%) and 20-29 (85 students or $44 \%)$. Students who perceived themselves with low-level blended learning engagement are the minority in all age groups, which were $11 \%$ for below 20 years old, $12 \%$ for $20-29$ years old, and $22 \%$ for over 29 years old.

In terms of students' ethnicity, interesting results were found as well. International students were found in very high and high-level of blended learning engagement (71\%) compared to the other groups in the same level such as Malay (47\%), Chinese (43\%), Sabah-Sarawak $(40 \%)$, and Indian (39\%). In all groups of students' ethnicities, lowlevel engagement was also the minority, which ranged from $26 \%$ (Indian students) to $8 \%$ (international students).

Analysis of students' field of study found that more than half of the engineering (51\%) and medical (56\%) students were in very high and high level of engagement. Natural science students were mostly in moderate level (53\%) of engagement. Similarly, a moderate level engagement was found for social sciences, engineering, and medicine students in the range of $34 \%$ to $37 \%$.

Finally, there was not much difference in any level of engagement from students in the public and private higher education institutions who participated in this study. For instance, students who were perceived as very high and high levels of engagement were $47 \%$ in 
the public university and $44 \%$ in the private university. Respectively, $15 \%$ and $11 \%$ students from the public and private universities were classified as low-level blended learning engagement.

Table 6

Students' Blended Learning Engagement Level According to Demographics

\begin{tabular}{|c|c|c|c|c|}
\hline Demographics & $\begin{array}{c}\text { Very } \\
\text { High } \\
\text { LVP > } \\
+4.28\end{array}$ & $\begin{array}{c}\text { High } \\
+4.26 \geq \\
\mathrm{LVP} \geq \\
+2.12\end{array}$ & $\begin{array}{c}\text { Moderate } \\
+2.12 \geq \\
\mathrm{LVP} \geq \\
-0.04\end{array}$ & $\begin{array}{c}\text { Low } \\
\text { LVP } \\
\leq-0.04\end{array}$ \\
\hline \multicolumn{5}{|l|}{ Gender } \\
\hline Male & 32 & 43 & 65 & 18 \\
\hline Female & 44 & 94 & 122 & 44 \\
\hline \multicolumn{5}{|l|}{ Age } \\
\hline Below 20 years old & 27 & 61 & 79 & 20 \\
\hline 20-29 years old & 30 & 55 & 86 & 24 \\
\hline Over 29 years old & 19 & 21 & 22 & 17 \\
\hline \multicolumn{5}{|l|}{ Ethnicity } \\
\hline Malay & 24 & 37 & 48 & 19 \\
\hline Chinese & 30 & 66 & 108 & 26 \\
\hline Indian & 6 & 10 & 14 & 11 \\
\hline Sabah \& Sarawak & 1 & 5 & 7 & 2 \\
\hline $\begin{array}{l}\text { International } \\
\text { students }\end{array}$ & 15 & 19 & 10 & 4 \\
\hline \multicolumn{5}{|l|}{ Field of Study } \\
\hline Social Sciences & 42 & 90 & 111 & 44 \\
\hline Natural Sciences & 15 & 14 & 44 & 10 \\
\hline Engineering & 5 & 13 & 12 & 5 \\
\hline Medicine & 12 & 17 & 19 & 3 \\
\hline \multicolumn{5}{|l|}{ Higher Institution } \\
\hline \multicolumn{5}{|l|}{ Type } \\
\hline Public & 48 & 71 & 92 & 39 \\
\hline Private & 28 & 66 & 95 & 23 \\
\hline
\end{tabular}


Differences in students' engagement in blended learning based on gender, age, ethnicity, field of study, and level of education

Further, an inferential statistics of testing differences of students' engagement in blended learning using analysis of variance (ANOVA) shows that only ethnicity has a significant difference at $p<0.05$ (Table 7). Other demographic variables such as gender, age, field of study, and type of institution do not show any significant difference statistically.

Table 7

ANOVA of Students' Demographic Variables

\begin{tabular}{lll}
\hline No & \multicolumn{1}{c}{ Demographic Variable } & F-test \\
\hline 1. & Gender & 1.988 \\
2. & Age & 0.208 \\
3. & Ethnicity & $3.349 *$ \\
4. & Field of Study & 2.359 \\
5. & Type of Higher Institution & 0.797 \\
\hline
\end{tabular}

note: $* p<0.05$

\section{Differential Item Functioning (DIF) of Respondents' Demographic Factors in Blended Learning Engagement}

The next stage of analysis is about differences between respondents' demographic variables and engagement in blended learning items. These were analysed using Differential Item Functioning (DIF) analysis, which suggests that respondents of separate subgroups respond differently to some items (Boone et al., 2014), thus measuring distinctive engagement at item level. The DIF analysis shows that all five demographic factors have significant difference responses (based on either DIF size $>0.5$ logits, $t>2.0$ or $p<0.05$ ) (Boone et al., 2014; Bond \& Fox, 2015) as shown in Table 8. There are nine items out of 16 that have DIF from different demographic variables. 
Table 8

Summary of Differential Item Functioning Based on Students' Demographic Variables

\begin{tabular}{|c|c|c|}
\hline Item & Statement & Demographic with DIF \\
\hline$C 2$ & $\begin{array}{l}\text { I am able to discuss assignments } \\
\text { with my classmates using } \\
\text { my university's learning } \\
\text { management systems (e.g., } \\
\text { Blackboard, Moodle). }\end{array}$ & $\begin{array}{l}\text { Age, Type of higher } \\
\text { institution }\end{array}$ \\
\hline $\mathrm{C} 3$ & $\begin{array}{l}\text { I prepare myself by reading } \\
\text { materials online before attending } \\
\text { classes. }\end{array}$ & Age \\
\hline E1 & $\begin{array}{l}\text { I am able to motivate myself to } \\
\text { learn when performing online } \\
\text { tasks. }\end{array}$ & Gender \\
\hline E2 & $\begin{array}{l}\text { I give importance to studying } \\
\text { together with my classmates in a } \\
\text { group online. }\end{array}$ & $\begin{array}{l}\text { Type of higher institution, } \\
\text { Field of study, and Age }\end{array}$ \\
\hline E4 & $\begin{array}{l}\text { I feel my classes are more } \\
\text { interesting when performing task } \\
\text { online with my classmates. }\end{array}$ & Field of study \\
\hline B1 & $\begin{array}{l}\text { I participate actively in online } \\
\text { activities. }\end{array}$ & Ethnicity \\
\hline B3 & $\begin{array}{l}\text { I listen carefully to my lecturers } \\
\text { in class on the required task to } \\
\text { perform online. }\end{array}$ & $\begin{array}{l}\text { Type of higher institution, } \\
\text { Field of study, and } \\
\text { Ethnicity }\end{array}$ \\
\hline B4 & $\begin{array}{l}\text { I do my assignments and submit } \\
\text { it on time online. }\end{array}$ & Field of study and Age \\
\hline B6 & $\begin{array}{l}\text { I try to do my best in online } \\
\text { group work. }\end{array}$ & Age \\
\hline
\end{tabular}

Based on the students' responses, there was one item, E1, identified to have a significant difference based on gender (Table 6). Male students tend to be able to motivate themselves when completing online learning compared to their female counterparts. For ethnicity, two items (B1 and B3) have DIF. In terms of participation in online activities (B1), the Indian and Chinese students perceived this 
difficult compared to other ethnic groups. For giving attention to perform online tasks, the Indian, Malay, and Sabah-Sarawak students found it is easier compared to the international and Chinese students. In terms of type of institution, item C2 and E2 were regarded as difficult by the public university students, but these students pay more attention to complete an online task (item B3) compared to the private university students.

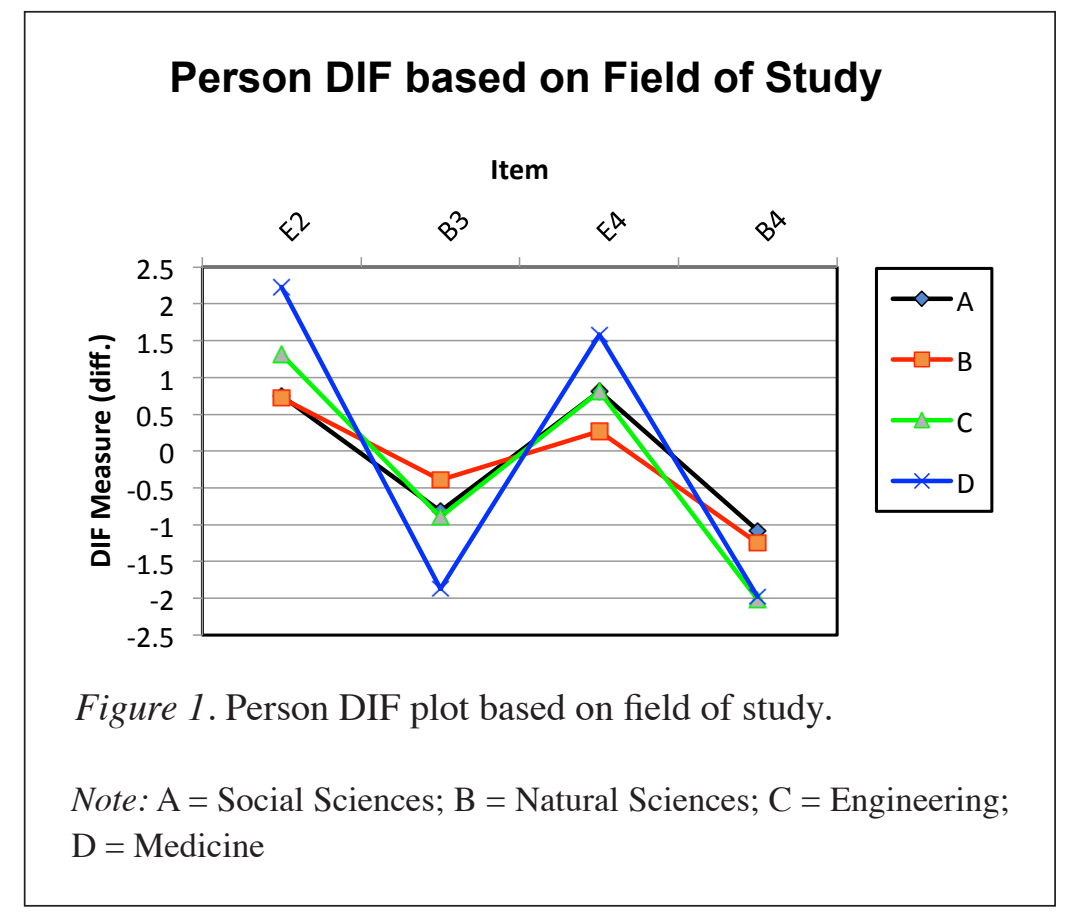

The DIF analysis based on students' field of study showed unique responses (Figure 1). Medical students found it difficult to study together (E2) and performing online task (E4) with their friends compared to the other groups. However, medical students prepared more in the online task (B3) than others. Engineering and medical students also tend to submit online in a timely manner compared to social sciences and natural sciences students (B4).

The DIF analysis based on students' age group (Figure 2) shows younger students (below 20 years) were more able to interact with their classmates in learning management system (C2) and studying together (E2) compared to other groups. Students under 30 years old 
could also submit an online task on time (B4) and work in an online platform (B6) compared to the older group. As for study preparations (C3), older students are more ready than others, possibly because of the advantage of their study experience.

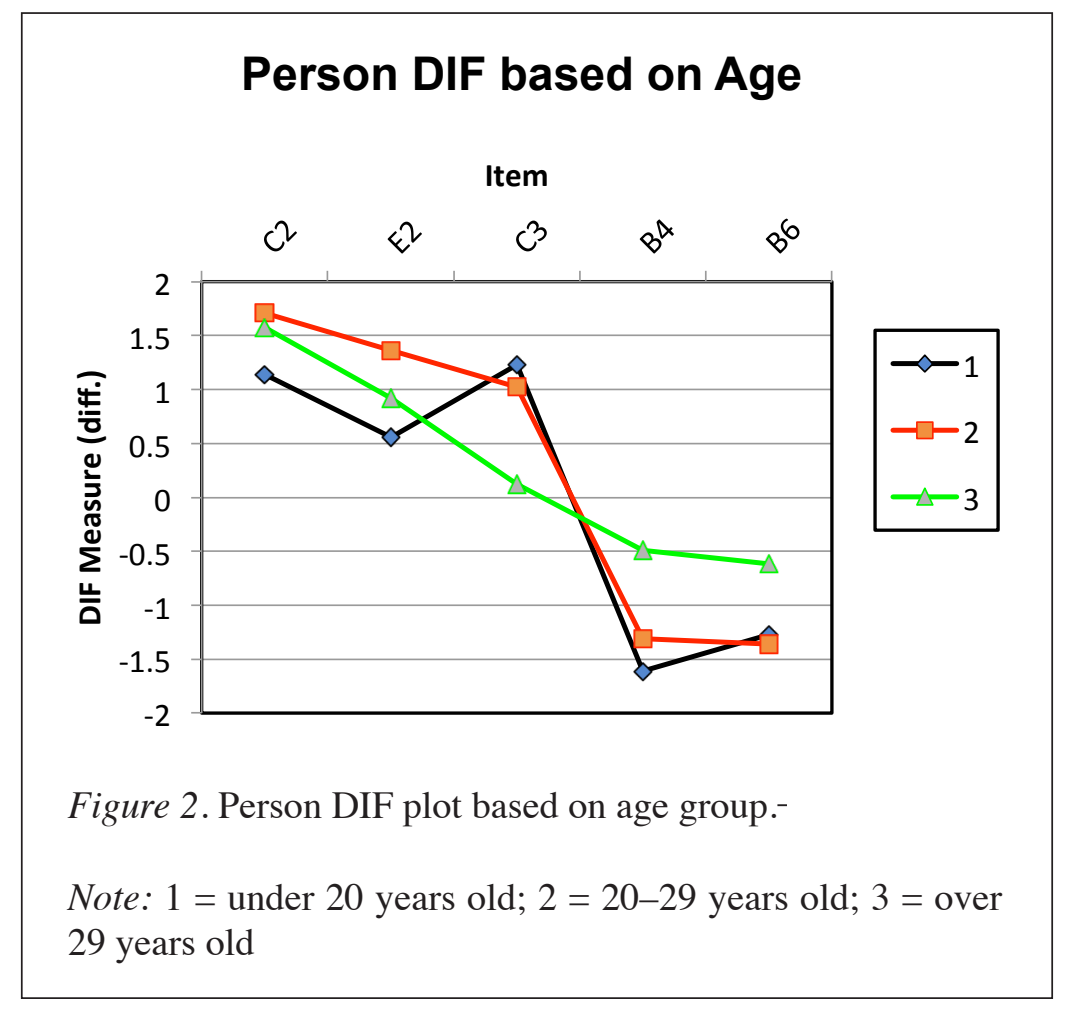

\section{DISCUSSION}

This study aimed to investigate students' engagement in a blended learning model of instruction based on cognitive engagement, emotional engagement, and behavioural engagement, and specifically assess their engagement based on gender, age, ethnicity, field of study, and type of institution in leading Malaysian public and private higher education institutions. First, the results of this study indicate high levels of engagement in blended learning activities among students in both public and private higher education institutions. This could be largely influenced by both institutions' policy and adoption practices to make online learning an integral component of higher education 
and lifelong learning in accordance with the Malaysia Education Blueprint's vision. It also seems possible that these results are due to the generation $\mathrm{Z}$, millennial, and digital natives era, of which these students are surrounded and engaged in technology all their life, and this influenced their way of learning. This finding is consistent with studies by Pellas and Kazanidis (2014) and Sarıtepeci and Çakır (2015) in which it was found that a blended learning course delivery engaged more students in online collaborative activities compared to face-to-face learning.

Second, students were found to have a high level of engagement in the area of behavioural engagement. This indicates students have a positive attitude and participation towards blended learning activities and complete the given task by lecturers. In terms of cognitive engagement, it is worth highlighting that most students in this study found it difficult to understand complex ideas and master difficult skills in a blended learning model of instruction. Cognitively engaged students usually do their own learning by planning, monitoring, and regularly review their progress on tasks (Mohd et al., 2016). Consequently, students also rated emotional engagement as very difficult in this study. This finding is hardly surprising as students need to be cognitively engaged before they can be emotionally engaged in a way that make them comfortable and connected to one another (Fredricks et al., 2004). Helme and Clarke (2001) supported this notion in that emotional and cognitive components of students' engagement support and complement one another in a synergistic manner. The response shows that students' emotional engagement is not always possible during effortful learning activities (Baker, D'mello, Rodrigo, Graesser, 2010). This finding corroborates with the results of another study, where lower levels of emotional engagement were associated with both active-learning activities and when students found the activities challenging (Manwaring et al., 2017). Therefore, it is important to know students' behaviour, feelings, and thinking that aid in the development of students' engagement in blended learning activities (Fredricks et al., 2004).

The findings also showed male students were more engaged in blended learning activities than female students. DIF analysis further indicates male students can self-motivate themselves when performing online tasks compared to female students. This could 
possibly mean male students were more excited to participate in online activities compared to female students (Win \& Wynn, 2015). Previous findings also reported that males differed significantly from females in online learning engagement (Islam, Abdul Rahim, Tan, \& Momtaz, 2011; Lau \& Shaikh, 2012). Naresh, Reddy, and Pricilda (2016) supported these findings when they found male students preferred technology for learning compared to females who preferred face-to-face learning. This indicates male students have more confidence in using technology for learning compared to female students (Yau \& Cheng, 2012).

In terms of students' age, students aged over 29 were found to be more engaged in blended learning activities by reading materials online and prepared for classes compared to the younger students. Furthermore, students aged below 20 prefer studying in a group, completing their assignments, and submitting it on time online. Students aged over 29 are usually those undertaking postgraduate courses. This shows postgraduate students and pre-university students were keener on a blended learning mode of instruction compared to undergraduate students who predominantly prefer class tutorials and face-to-face instruction. Similar findings were reported by Adams et al. (2018) who also found mature students, compared to younger students, were more engaged and adaptable in blended learning activities. It can be interpreted here that postgraduate students are more mature and independent leaners in utilising information technology for their learning. Pre-university students, on the other hand, are more receptive towards blended learning as they are keen to try new ways of learning compared to their schooling years.

As for students' ethnicity, findings indicate international students were highly engaged in blended learning activities compared to the other ethnic groups. Studies have indicated international students possess significant internal motivation to engage with unfamiliar technology (Prasad, Maag, Redestowicz, \& Hoe, 2018). This finding corroborates with the results of another study, where international students were reported to be more active in a blended learning model of instruction compared to other ethnicities (Adams et al., 2018; Lau \& Shaikh, 2012). Moveover, DIF analysis indicated there were differences in terms of ethnicity on students' blended learning engagement on two items. The Indian and Chinese students were less participative in online activities compared to the international, 
Malay, and Sabah-Sarawak students. Additionally, the Indian, Malay, and Sabah-Sarawak students listened to their lecturers more attentively on the required tasks to perform online compared to the international and Chinese students. This finding is supported by other studies reporting the significant difference in learning preference based on ethnicity (Lau \& Shaikh, 2012). However, Islam et al. (2011) claimed that students' ethnicity did not have any influence on their engagement in blended learning activities. Due to inconsistent findings across students' ethnicity, we propose further research in this area, especially a qualitative study, to further explore these findings.

Finally, findings of students' field of study show students from engineering and medicine were highly engaged in blended learning activities compared to students from social sciences and natural sciences. However, a closer look at the DIF analysis found medical students face greater difficulty to study and perform online task with their friends compared to the other groups. Thus, unsurprisingly they are better prepared for online task. Engineering and medical students also tend to submit online in a timely manner compared to social sciences and natural sciences students. This is an interesting finding as other studies have reported that students' field of study did not have any influence on their engagement in blended learning activities (see Lau \& Shaikh, 2012; Rasouli, Rahbania, \& Attaran, 2016). There is evidence that medical students are often biased in how they select new information to learn (Gureckis \& Markant, 2012). Thus, medical students can self-teach basic knowledge online but require tutorial classes for higher-level thinking skills such as synthesis or evaluation of knowledge (Morton et al., 2016). The challenge for medical educators is to ensure students' engagement with the online self-directed component of modules with careful consideration on large numbers of students.

\section{CONCLUSION}

Overall findings of this study revealed high levels of engagement in blended learning activities among students in both public and private higher education institutions. However, further analysis indicated there were differences in students' engagement based on gender, age, ethnicity, field of study, and type of institution. Blended learning activities and its facilitation online need to devised according to 
students' interest, competence, and skills. Lecturers must be able to maintain control, at the same time possess technical 'know how' to design activities that promote high levels of students' engagement in online learning.

According to Garrison and Kanuka (2004, p. 104), a blended learning form of teaching and learning will 'redefine higher education institutions as being learning-centred and facilitate a higher learning experience'. However, the degree of students' engagement in blended or online university courses must be analysed carefully. Otherwise, a blended learning model of instruction in higher education institutions might be heading towards an implementation failure (Kintu, Zhu, \& Kagambe, 2017).

This study comes with several limitations of its own. First, the study's sample size is small due to its concentration on only two public and private higher education institutions in Kuala Lumpur, Malaysia. Therefore, we suggest future studies to be expanded to other public and private higher education institutions, consist of a larger sample size, and with the added perspective from lecturers as well. Second, the current study is limited to only a quantitative cross-sectional research design. As such, future studies could add qualitative data such as interviews to further explore and explain the findings in depth. Furthermore, investigating what specific blended learning activities are most effective in engaging students from different fields of studies would significantly expand the current body of knowledge.

We conclude that the implementation of a blended learning model of instruction is closely tied with institutional policy and adoption practices. As the thrust towards implementing blended learning in courses gathers pace and continues to grow in popularity and demand, training programmes and support systems must be developed and put in place to ease the adaption process for both students and lecturers (Rasouli, Rahbania, \& Attaran, 2016).

\section{ACKNOWLEDGEMENT}

This research was funded by the Bantuan Kecil Penyelidikan (BKP) (BK031-2017) grant under the University of Malaya. 


\section{REFERENCES}

Acelajado, M. J. (2011). Blended learning: A strategy for improving the mathematics achievement of students in a bridging program. Electronic Journal of Mathematics and Technology, 5(3), 342-352.

Adams, D., Sumintono, B., Mohamed, A., \& Mohamad Noor, N. S. (2018). E-learning readiness among students of diverse backgrounds in a leading Malaysian higher education institution. Malaysian Journal of Learning and Instruction, 15(2), 227-256.

A. Ghani, M. F. (2013). Educational management in Malaysia. Kuala Lumpur: University of Malaya Press.

Azizan,F.Z. (2010). Blended learning in higher education institution in Malaysia. Proceedings of the Regional Conference on Knowledge Integration in ICT, Selangor, 454-466.

Baker, R. S. J. d., D’Mello, S. K., Rodrigo, M. M. T., \& Graesser, A. C. (2010). Better to be frustrated than bored: The incidence, persistence, and impact of learners' cognitive affective states during interactions with three different computer-based learning environments. International Journal of HumanComputer Studies, 68(4), 223-241.

Bernard, R. M., Borokhovski, E., Schmid, R. F., Tamim, R. M., \& Abrami, P. C. (2014). A meta-analysis of blended learning and technology use in higher education: From the general to the applied. Journal of Computing in Higher Education, 26(1), $87-122$.

Bond, T. G., \& Fox, C. M. (2015). Applying the Rasch model: Fundamental measurement in the human sciences (3rd ed.). New York: Routledge.

Boone, W. J., Staver, J. R., \& Yale, M. S. (2014). Rasch analysis in the human sciences. Dordrecht: Springer.

Boone, W. J., Townsend, J. S., \& Staver, J. R. (2016). Utilizing multifaceted Rasch measurement through FACETS to evaluate science education data sets composed of judges, respondents, and rating scale items: An exemplar utilizing the elementary science teaching analysis matrix instrument. Science Education, 100(2), 221-238.

Curley, A., McClure, G., Spence, D., \& Craig, S. (2002). The new NHS: Modern, definable? Aquestionnaire to assess knowledge of, and attitudes to, the new NHS. Clinician in Management 11(1), 15-23. 
Drysdale, J. S., Graham, C. R., Spring, K. J., \& Halverson, L. R. (2013). An analysis of research trends in dissertations and theses studying blended learning. The Internet and Higher Education, 17, 90-100. https://doi.org/10.1016/j. iheduc.2012.11.003

Dziuban, C., Graham, C. R., Moskal, P. D., Norberg, A., \& Sicilia, N. (2018). Blended learning: The new normal and emerging technologies.International Journal of Educational Technology in Higher Education, 15(3), 2-16.

Engelhard, G., Jr. (2013). Invariant measurement: Using Rasch models in the social, behavioral and health sciences. New York: Routledge.

Fisher, R., Perényi, Á., \& Birdthistle, N. (2018). The positive relationship between flipped and blended learning and student engagement, performance and satisfaction. Active Learning in Higher Education, 1-17. https://doi. org/10.1177/1469787418801702

Fredricks, J. A., Blumenfeld, P. C., \& Paris, A. H. (2004). School engagement: Potential of the concept, state of the evidence. Review of Educational Research, 74(1), 59-109. https://doi. org/10.3102/00346543074001059

Garrison, D. R., \& Kanuka, H. (2004). Blended learning: Uncovering its transformative potential in higher education. Internet and Higher Education, 7(2), 95-105.

Graham, C. R., Woodfield, W., \& Harrison, J. B. (2013). A framework for institutional adoption and implementation of blended learning in higher education. The Internet and Higher Education, 18, 4-14. https://doi.org/10.1016/j. iheduc.2012.09.003

Gureckis, T. M., \& Markant, D. B. (2012). Self-directed learning: A cognitive and computational perspective. Perspectives on Psychological Science, 7(5), 464-481.

Halverson, L. R., \& Graham, C. R. (2019). Learner engagement in blended learning environments: A conceptual framework. Online Learning, 23(2), 145-178. https://doi.org/10.24059/ olj.v23i2.1481

Helme, S., \& Clarke, D. (2001). Identifying cognitive engagement in the mathematics classroom. Mathematics Education Research Journal, 13(2), 133-153.

Henrie, C. R., Bodily, R., Manwaring, K. C., \& Graham, C. R. (2015). Exploring intensive longitudinal measures of student 
engagement in blended learning. The International Review of Research in Open and Distributed Learning, 16(3), 131-155. https://doi.org/10.19173/irrodl.v16i3.2015

Islam, M. A., Abdul Rahim, N. A., Tan, C. L., \& Momtaz, H. (2011). Effect of demographic factors on e-learning effectiveness in a higher learning institution in Malaysia. International Education Studies, 4(1), 112-121.

Kintu, M. J., Zhu, C., \& Kagambe, E. (2017). Blended learning effectiveness: The relationship between student characteristics, design features and outcomes. International Journal of Educational Technology in Higher Education, 14(7). https:// doi.org/10.1186/s41239-017-0043-4

Lau, C. Y., \& Shaikh, J. M. (2012). The impacts of personal qualities on online learning readiness at Curtin Sarawak Malaysia (CSM). Educational Research and Reviews, 7(20), 430-444.

Lim, D. H., \& Morris, M. L. (2009), Learner and instructional factors influencing learning outcomes within a blended learning environment. Educational Technology \& Society, 12(4), 282293.

Maarop, A. H., \& Embi, M. A. (2016). Implementation of blended learning in higher learning institutions: A review of literature. International Education Studies, 9(3), 41. https://doi. org/10.5539/ies.v9n3p41

Manwaring, K. C., Larsen, R., Graham, C. R., Henrie, C. R., \& Halverson, L. R. (2017). Investigating student engagement in blended learning settings using experience sampling and structural equation modeling. Internet and Higher Education, 35(1), 21-33. https://doi.org/10.1016/j.iheduc.2017.06.002

Maroco, J., Maroco, A. L., Campos, J. A. D. B., \& Fredricks, J. A. (2016). University student's engagement: Development of the University Student Engagement Inventory (USEI). Psicologia: Reflexão e Crítica, 29(21), 1-12. https://doi. org/10.1186/s41155-016-0042-8

Ministry of Education Malaysia. (2013). Malaysia Education Blueprint: 2013-2025. Retrieved from https://www.moe.gov. my/dasar/1207-malaysia-education-blueprint-2013-2025/file

Mohd, I. H., Hussein, N., Aluwi, A. H., \& Omar, M. K. (2016). Enhancing students engagement through blended learning satisfaction and lecturersupport.In2016IEEE 8thInternational Conference on Engineering Education (ICEED): Enhancing Engineering Education through Academia-Industry Collaboration (pp. 175-180). Kuala Lumpur, December 7-8. 
Morton, C. E., Saleh, S. N., Smith, S. F., Hemani, A., Ameen, A., Bennie, T. D., \& Toro-Troconis, M. (2016). Blended learning: How can we optimise undergraduate student engagement? BMC Medical Education, 16, 195.

Naresh, B., Reddy, B. S., \& Pricilda, U. (2016). A study on the relationship between demographic factor and e-learning readiness among students in higher education. Sona Global Management Review, 10(4), 1-11.

Northey, G., Bucic, T., Chylinski, M., \& Govind, R. (2015). Increasing student engagement using asynchronous learning. Journal of Marketing Education, 37(3), 171-180. https://doi. org/10.1177/0273475315589814

Pellas, N., \& Kazanidis, I. (2015). On the value of second life for students' engagement in blended and online courses: A comparative study from the higher education in Greece. Education and Information Technologies, 20(3), 445-466. https://doi.org/10.1007/s10639-013-9294-4

Prasad, P. W. C., Maag, A., Redestowicz, M., \& Hoe, L. S. (2018). Unfamiliar technology: Reaction of international students to blended learning. Computers \& Education, 122, 92-103.

Rasouli, A., Rahbania, Z., \& Attaran, M. (2016). Students' readiness for e-learning application in higher education. Malaysian Online Journal of Educational Technology, 4(3), 51-64.

Ryan, S., Kaufman, J., Greenhouse, J., She, R., \& Shi, J. (2016). The effectiveness of blended online learning courses at the community college level. Community College Journal of Research and Practice, 40(4), 285-298.

Sarıtepeci, M., \& Çakır, H. (2015). The effect of blended learning environments on student motivation and student engagement: A study on social studies course. Education and Science, 40(177), 203-216. https://doi.org/10.15390/EB .2015.2592

Southard, S., Meddaugh, J., \& France-Harris, A. (2015). Can SPOC (self-paced online course) live long and prosper? A comparison study of a new species of online course delivery. Online Journal of Distance Learning Administration, 18(2). Retrieved from http://www.westga.edu/ distance/ojdla/

Sumintono, B., \& Widhiarso, W. (2013). Aplikasi model Rasch untuk penelitian ilmu-ilmu sosial (edisi revisi) [Application of rasch modelling in social science research, revised edition]. Cimahi: Trimkom Publishing House.

Tayebinik, M., \& Puteh, M. (2012). Blended learning or e-learning? International Magazine on Advances in Computer Science and Telecommunications, 3(1), 103-110. 
Vibert, A., \& Shields, C. (2003). Approaches to student engagement: Does ideology matter? McGill Journal of Education, 38(2), 221-240.

Wang, M. J. (2010). Online collaboration and offline interaction between students using asynchronous tools in blended learning. Australasian Journal of Educational Technology, 26(6), 830-846.

Win, N. L., \& Wynn, S. D. (2015). Introducing blended learning practices in our classrooms. Journal of Institutional Research in South East Asia, 13(2), 17-27.

Yau, H. K., \& Cheng,A. L. F. (2012). Gender difference of confidence in using technology for learning. The Journal of Technology Studies, 38(2), 74-79. 